\title{
Termites as Protein Source for Economic Production of Japanese Quail
}

\author{
Nethee Deori ${ }^{1}$, Reema Saikia ${ }^{2}$ and Rajkishor Gogoi ${ }^{3 *}$ \\ ${ }^{1}$ Department of Livestock Farm Complex, A.C.V.M., Jaipur, Rajasthan, India \\ ${ }^{2}$ Department of Poultry Science, C.V.Sc., Guwahati, Assam, India \\ ${ }^{3}$ Department of Pharmacology \& Toxicology, A.C.V.M., Jaipur, Rajasthan, India \\ *Corresponding author
}

\section{Keywords \\ Assam, Japanese quail, \\ Supplementary \\ Protein Source, \\ Termites \\ Article Info \\ Accepted: \\ 15 May 2019 \\ Available Online: \\ 10 June 2019}

\section{A B S T R A C T}

The present investigation has been contemplated to study the economic production of Japanese quails fed on locally available termites during rainy season as protein source for wider applicability in promoting small scale low cost quail farming in Assam. In the present study about 180 numbers of day old unsexed Japanese quail chicks from a single hatch was procured and randomly divided into four equal groups i.e. $\mathrm{T}_{0}$ (control), $\mathrm{T}_{1}(5 \%$ dried termite), $\mathrm{T}_{2}$ (10\% dried termite) and $\mathrm{T}_{3}$ (15\% dried termite) containing 45 numbers of chicks in each group which was further subdivided into 3 replicates of 15 chicks in each. The chicks were maintained following standard feeding and uniform managemental practices under cage system of rearing. For preparation of termite meal local species of termites were collected from various regions of Assam by shoving termiterium with the spade to discomfort them and they will erupt and come out which is then brushed into plastic container. Then they were soaked in a tub of water for a minute to die. After that they were sieved with a traditional bamboo strainer followed by drying in hot air oven at $60^{\circ} \mathrm{C}$ for 12 hours and used in quail starter and finisher feed for a period of 6 weeks. The cost of production per Japanese quail including the additional cost of dried termite was highest in $\mathrm{T}_{3}$ (Rs. 96.09) followed by $\mathrm{T}_{2}$ (Rs. 90.29), $\mathrm{T}_{1}$ (Rs. 83.75) and $\mathrm{T}_{0}$ (Rs. 56.87) group. However, the gross profit per Japanese quail was found to be highest in $\mathrm{T}_{3}$ group (Rs. 23.49) followed by $\mathrm{T}_{2}$ (Rs. 18.86), $\mathrm{T}_{1}$ (Rs. 14.52) and $\mathrm{T}_{0}$ (Rs. 10.94) group. Thus, it is concluded that the inclusion of dried termite in the basal diet can be used effectively and economically as an alternative protein source in commercial Japanese quail feed.

\section{Introduction}

Poultry industry is a major source of animal protein in both developed and developing countries. The poultry industry has expanded rapidly in developing countries in the last two decades. Global demand for animal-source food is accelerating rapidly due to population growth and economic development, particularly in developing countries. This increase in population growth estimated to be 8.1 billion in 2030 and 9 billion in 2050 will lead to the animal protein requirements and demands increasing (Godfray et al., 2010). Over one billion people in developing countries are suffering from malnutrition and 
protein deficiency that are closely associated with poverty. Nowadays, poverty reduction largely focuses on poultry farming. Poultry meat contributes approximately $370 \mathrm{~g} / \mathrm{kg}$ to the total animal protein supply.

However, the progress made so far in the poultry sector is currently being undetermined by escalating cost of their feeds, increasing competitive demand for them by man and animals, and scarcity of the conventional animal protein source, that is fish meal and plant protein sources. Therefore, to reduce the feed cost, which accounts for 75 to $80 \%$ of the total cost of production, efforts are being geared towards evaluating alternative, good quality renewable protein sources that can replace or substitute scarce, expensive and elusive conventional protein sources used in poultry nutrition. Therefore there is a need to exploit not only the known unconventional feed ingredients but also to determine and introduce new and lesser known plants animal feed resources.

According to Teguia and Beynen (2005), the major ingredients of poultry feeds are maize and imported protein concentrate based on soya bean concentrate, fish and / or animal meals. Presently, the protein sources such as fishmeal are very expensive, especially for small holder farmers. As a result, the demand for low cost poultry feed is high, due to the rising cost and a limited supply of commercial feeds. Gope and Prasad (1983) mentioned that insects represent the cheapest source of animal protein.

Not all insets are safe to use in animal feed. Just as it applies for plants and animal food products some insects cause allergic reactions, botulism, parasitizes and food poisoning (Yen, 2010). Insects such as the black soldier fly, common housefly, termites and yellow mealworm are the most promising insects in animal feed.
Termites are social insects that swarm seasonally especially at the onset of rainy season or after heavy rainfall. They are valuable sources of protein, fat and essential amino acids which can contribute to the reduction in the protein deficiencies (Omotoso, 2006). They, however, thrive well in dry conditions and mostly feed on deep plant materials such as wood, leaf litter and animal slurry (Okeno et al., 2012). Termites are among the threating pests in crop production and forestry. Harvesting them from their mounds, frame doors and other cellulosic materials will decrease their numbers and become less effective. Termites can be collected by shoving termiterium with the spade to discomfort them and they will erupt and come out. Termites can be fed to chickens as fresh without processing (Men et al., 2004). They can also be roasted to make termite meal (Ntukuyoh et al., 2012).

Termites are a valuable source of protein, fat and essential amino acids in the diet for both primates and humans. As a high source of protein termites can be used in poultry diets to support growth and maintenance of the body of poultry.

Japanese quail (Coturnix japonica) is a diversified poultry species reared for commercial egg and meat production. It is blessed with the unique characteristics of low maintenance cost, easy handling, fast growth, early sexual maturity, less space requirement and being robust to many of the avian diseases, high rate of egg production, short generation interval and valuable taste and dietary properties of quail meat. Layer quail start laying eggs within their six to seven weeks of age. They can lay about 280 eggs per year.

Keeping the above facts in view the present investigation has been contemplated to study the economic production of Japanese quails 
fed on locally available termites during rainy season as protein source for wider applicability in promoting small scale low cost quail farming in Assam.

\section{Materials and Methods}

\section{Location of work}

The present work was conducted in the Experimental Poultry Shed of Instructional Poultry Farm (IPF), College of Veterinary Science, Assam Agricultural University, Khanapara, Guwahati, Assam.

\section{Management of experimental birds}

The poultry shed and battery cages were thoroughly cleaned and disinfected before the arrival of the chicks. The equipments like feeders, drinkers were cleaned, washed and disinfected properly. The quail chicks were kept in cages throughout the experimental period following standard and uniform managemental procedures. Feed and water were provided ad libitum and necessary medications were given as per standard schedule.

\section{Preparation of Termite Meal}

Local species of termites were collected from various regions of Assam by shoving termiterium with the spade to discomfort them and they will erupt and come out which is then brushed into plastic container. Then they were soaked in a tub of water for a minute to die. After that they were sieved with a traditional bamboo strainer followed by drying in hot air oven at $60^{\circ} \mathrm{C}$ for 12 hours.

\section{Design of experiment}

For the experimental trial, 180 numbers of Japanese quail day old chicks having similar body weight from a single hatch were procured from the Instructional Poultry Farm, College of Veterinary Science, Khanapara.

The chicks were weighed; wing banded and randomly divided into four groups' viz. $\mathrm{T}_{0}, \mathrm{~T}_{1}$, $\mathrm{T}_{2}$ and $\mathrm{T}_{3}$ containing 45 chicks in each group. Each group was further subdivided into 3 replicates of 15 chicks each.

The chicks were maintained following standard feeding and uniform managemental practices under cage system of rearing.

$\mathrm{T}_{0}-$ Basal diet

$\mathrm{T}_{1}$ - Inclusion of $5 \%$ dried termite with the basal diet

$\mathrm{T}_{2}$ - Inclusion of $10 \%$ dried termite with the basal diet

$\mathrm{T}_{3}$ - Inclusion of $15 \%$ dried termite with the basal diet

\section{Experimental diet}

The experimental diets were designed as diet $\mathrm{T}_{0}, \mathrm{~T}_{1}, \mathrm{~T}_{2}$ and $\mathrm{T}_{3}$. Diet $\mathrm{T}_{0}$ served as control (with no termite supplementation) while diet $\mathrm{T}_{1}, \mathrm{~T}_{2}$ and $\mathrm{T}_{3}$ contained $5 \%, 10 \%$ and $15 \%$ of dried termite, respectively.

The Japanese quail chicks were fed quail starter (0-3 weeks) and finisher (4-6 weeks) diets as per Indian Council of Agricultural Research (2013) containing the feedstuffs namely maize, rice polish, soya bean meal, ground nut cake, mineral mixture and common salt at the recommended levels.

\section{Calculation of economics of production}

The average cost of production per Japanese quail under various treatment groups was calculated using the following components. 
Table.1 Cost of production and gross profit (Rs.) per Japanese quail under different treatment groups

\begin{tabular}{|c|c|c|c|c|c|c|c|c|c|c|c|}
\hline \multirow{2}{*}{$\begin{array}{l}\text { Experimental } \\
\text { Groups }\end{array}$} & \multicolumn{3}{|c|}{ Items of expenditure } & \multirow{2}{*}{$\begin{array}{l}\text { Additional cost } \\
\text { of dried } \\
\text { termite } \\
\text { (transportation } \\
+ \text { cost of } \\
\text { drying) (D) } \\
\text { (Rs.) }\end{array}$} & \multirow{2}{*}{\multicolumn{2}{|c|}{$\begin{array}{l}\text { Total } \\
\text { production } \\
\text { cost }(\mathrm{E}) \\
(\mathrm{A}+\mathrm{B}+\mathrm{C}+\mathrm{D}) \\
(\text { Rs. })\end{array}$}} & \multirow{2}{*}{$\begin{array}{l}\text { Production } \\
\text { cost / bird } \\
\text { (F) (Rs.) }\end{array}$} & \multirow{2}{*}{$\begin{array}{l}\text { Total } \\
\text { saleable } \\
\text { live } \\
\text { weight } \\
\text { (kg) } \\
\text { (G) }\end{array}$} & \multirow{2}{*}{$\begin{array}{l}\begin{array}{l}\text { II. } \\
\text { Return } \\
\text { (H) }\end{array} \\
\\
\\
\text { 1.Total } \\
\text { saleable } \\
\text { live } \\
\text { weight } \\
\text { X } \\
\text { Rs.270 } \\
\text { per kg } \\
\text { (G) }\end{array}$} & \multirow{2}{*}{$\begin{array}{l}\text { III. } \\
\text { Gross } \\
\text { Profit } \\
\text { (E - G) } \\
\text { (Rs.) } \\
\text { (I) }\end{array}$} & \multirow{2}{*}{$\begin{array}{l}\text { IV. } \\
\text { Gross } \\
\text { profit } \\
/ \\
\text { bird } \\
\text { (J) } \\
\text { (Rs.) }\end{array}$} \\
\hline & $\begin{array}{l}\text { Chick } \\
\text { cost } \\
\text { (A) } \\
\text { (Rs.) } \\
(\mathrm{n}= \\
45)^{*}\end{array}$ & $\begin{array}{l}\text { Feed } \\
\text { cost (B) } \\
\text { (Rs.) }\end{array}$ & $\begin{array}{l}\text { Miscellaneous } \\
(\mathrm{C}) \\
15 \% \text { of } \\
(\mathrm{A}+\mathrm{B}+)(\mathrm{Rs} .)\end{array}$ & & & & & & & & \\
\hline $\mathbf{T}_{0}$ (control) & 990.00 & 1136.55 & 318.98 & - & 2445.53 & & 56.87 & $\begin{array}{l}10.80 \\
(n=43)^{*}\end{array}$ & 2916.00 & 470.47 & 10.94 \\
\hline $\begin{array}{l}\mathrm{T}_{1} \\
(5 \% \text { dried } \\
\text { termite })\end{array}$ & 990.00 & 1025.47 & 302.32 & 1200.00 & 3517.79 & & 83.75 & $\begin{array}{l}10.77 \\
(n=42)^{*}\end{array}$ & 2907.90 & 609.89 & 14.52 \\
\hline $\begin{array}{l}T_{2} \\
(10 \% \text { dried } \\
\text { termite })\end{array}$ & 990.00 & 1073.49 & 309.52 & 1600.00 & 3973.01 & & 90.29 & $\begin{array}{l}11.64 \\
(n=44)^{*}\end{array}$ & 3142.80 & 830.21 & 18.86 \\
\hline $\begin{array}{l}T_{3} \\
(15 \% \text { dried } \\
\text { termite })\end{array}$ & 990.00 & 1031.29 & 303.19 & 2000.00 & 4324.48 & & 96.09 & $\begin{array}{l}12.10 \\
(\mathrm{n}=45)^{*}\end{array}$ & 3267.00 & 1057.48 & 23.49 \\
\hline & \multicolumn{9}{|c|}{${ }^{*} \mathrm{n}=$ number of birds } & & \\
\hline & \multicolumn{2}{|c|}{ GROUP } & $\begin{array}{l}\mathbf{T}_{0} \\
\text { (control) }\end{array}$ & \multicolumn{2}{|c|}{$\begin{array}{l}\mathbf{T}_{1} \\
\text { (5\% dried } \\
\text { termite) }\end{array}$} & & $\begin{array}{l}\% \text { dried } \\
\text { mite) }\end{array}$ & \multicolumn{2}{|c|}{$\begin{array}{l}\mathrm{T}_{3} \\
(\mathbf{1 5 \%} \text { dried } \\
\text { termite) }\end{array}$} & & \\
\hline & \multicolumn{2}{|c|}{$\begin{array}{l}\text { Cost of feed per } \\
\text { kg (Rs.) }\end{array}$} & 31.13 & \multicolumn{2}{|l|}{28.25} & & 42 & \multicolumn{2}{|c|}{25.37} & & \\
\hline
\end{tabular}

Production cost

Chick cost $($ Rs. $)=$ Number of chick $x$ cost per chick

Production cost per bird = Total production cost

Number of chicks

Feed cost $($ Rs. $)=$ Calculated value of feed

Return

cost

Miscellaneous expenditure $=$ Add $15 \%$ of $\mathrm{A}+\mathrm{B}$ weight of saleable birds x Price of Japanese quail

Total production cost $($ Rs. $)=\mathrm{A}+\mathrm{B}+\mathrm{C}$

Gross profit $=$ Return - total production cost 
Gross profit per Japanese quail = Total number of birds sold

\section{Results and Discussion}

The experiment were conducted at the experimental poultry shed of the Department of Poultry Science, College of Veterinary Science, Assam Agricultural University, Guwahati. 180 numbers of day old unsexed Japanese quail chicks from a single hatch were procured and randomly divided into four equal group's viz. $\mathrm{T}_{0}, \mathrm{~T}_{1}, \mathrm{~T}_{2}$ and $\mathrm{T}_{3}$ containing 45 numbers of birds in each group which was further subdivided into 3 replicates of 15 chicks in each.

The chicks were wing banded and were maintained following standard feeding and uniform managemental practices under cage system of rearing.

For preparation of termite meal, local species of termite were collected from various regions of Assam by shoving termiterium with the spade to discomfort them and they will erupt and come out which is then brushed into plastic container. Then they were soaked in a tub of water for a minute to die. After that they were shieved with a traditional bamboo strainer followed by drying in hot air oven at $60^{\circ} \mathrm{C}$ for 12 hours. The termite meal was incorporated into the basal diet of Japanese quail at the levels of 5,10 and $15 \%$ on dry matter basis.

As shown in Table 1 the cost of production per Japanese quail was found to be (Rs.) 56.87, 83.75, 90.29 and 96.09 for $\mathrm{T}_{0}, \mathrm{~T}_{1}, \mathrm{~T}_{2}$ and $\mathrm{T}_{3}$ groups, respectively. The cost of production per quail was found to be highest in $T_{3}$ group as compared to $T_{0}, T_{1}$ and $T_{2}$ groups. However, gross profit per quail was found to be highest in $T_{3}$ (Rs. 23.49) group followed by $\mathrm{T}_{2}$ (Rs. 18.86), $\mathrm{T}_{1}$ (Rs. 14.52) and $\mathrm{T}_{0}$ (Rs. 10.94) groups. Thus among the four experimental groups, the $T_{3}(15 \%$ dried termite) showed best result in respect of higher gross profit per Japanese quail.

In conclusion, the present research provides new data and knowledge on the potential application and benefits of using termites as feed ingredients for economic production of Japanese quails. Termite meal showed to be a promising protein source for economic production of Japanese quails.

\section{Acknowledgement}

The authors acknowledge the help and technical support received from College of Veterinary Science, Assam Agricultural University, Khanapara during the course of the present investigation.

\section{References}

Godfray, H. Charles J.; Crute, Ian R.; Haddad, Lawrence; Lawrence, David; Muir, James F.; Nisbett, Nicholas; Pretty, Jules; Robinson, Sherman; Toulmin, Camilla and Whiteley, Rosalind. Phil. Trans. R. Soc. B 365: 2769-2777.

Gope, B. and Prasad, B. (1983). Preleminary observation on the nutritional value of some edible insects of Manipur. Journal of Advanced Zoology, 4: 5561.

Men, Bui Xuan.; Ogle, Brian and Preston, TR. (2004). Production and evaluation of Black Soldier fly larvae and termites as protein supplement for chickens. Workshop- Seminar "Making better use of local feed resources". Article \#24. 23-25.

Ntukuyoh, A.I.; Udiong, D.S.; Ikpe, E. and Akpakpan, A.E. (2012). Evaluation of Nutritional Value of Termites (Macrotermes bellicosus): Soldiers, Workers and Queen in the Niger Delta 
Regions of Nigeria. International Journal of Food Nutrition and Safety, 1(2): 60-65.

Okeno, T.O., Kahi, A.K., and Peters, K.J. (2012). Characterization of indigenous chicken production systems in Kenya. Tropical Animal Health and Production 44: 601-608.

Omotoso, OT. (2006). Nutritional quality, functional properties and anti-nutrient compositions of the larva of Cirina forda (Westwood) (Lepidoptera: Saturniidae). Journal of Zhejiang
University Science B, 7(1): 51-55.

Teguia, A. and Beynen, AC. (2005). Alternative feedstuffs for broilers in Cameroon. Livestock Research for Rural Development 17 (3).

Yen, A.L. (2010). Insects and other invertebrate foods of the Australian aborigines. In M.G. Paoletti, ed. Ecological implications of mini livestock: potential of insects, rodents, frogs and snails, New Hampshire, USA, Science Publishers, pp. 367-388.

\section{How to cite this article:}

Nethee Deori, Reema Saikia and Rajkishor Gogoi. 2019. Termites as Protein Source for Economic Production of Japanese Quail. Int.J.Curr.Microbiol.App.Sci. 8(06): 1886-1891. doi: https://doi.org/10.20546/ijcmas.2019.806.226 